\title{
Developing Innovative Chemistry Laboratory Workbook Integrated with Project-based Learning and Character-based Chemistry
}

\section{Bajoka Nainggolan}

Postgraduate Students, Department of Chemistry Education, Graduate Study Program, Universitas Negeri Medan, Indonesia, nainggolanbajoka@gmail.com

\section{Wesly Hutabarat}

Prof., Department of Chemistry, Faculty of Mathematics and Natural Sciences (FMIPA), Universitas Negeri Medan, Indonesia,wesly123@unimed.ac.id

\section{Manihar Situmorang}

Prof., corresponding author, Department of Chemistry, Faculty of Mathematics and Natural Sciences, Universitas Negeri Medan, Indonesia, msitumorang@ unimed.ac.id

\section{Marham Sitorus}

Dr., Department of Chemistry, Faculty of Mathematics and Natural Sciences (FMIPA), Universitas Negeri Medan, Indonesia, marham@ unimed.ac.id

The research was carried out through research and development to produce an innovative chemistry laboratory workbook (InoChemLaW) followed by the implementation of the learning package in the teaching of chemistry. The result showed that a standard InoChemLaW has successfully been developed on the topic of Colligative Properties of solutions. The implementation of InoChemLaW was carried out onto the experimental class compared to the existing laboratory workbooks (ConChemLaW) in the control class. An InoChemLaW package helps the students to learn chemistry independently so that the learning stages are carried out systematically, the students are actively completed the projects, thereby increasing their knowledge and skills. Students' knowledge and skills respectively in experimental groups were found higher than that in control group, and both groups are significantly different. The developed InoChemLaw package is highly very good. It is recommended that innovative laboratory workbooks integrated with project-based learning can be developed and implemented for teaching of other chemistry subjects and science studies.

Keywords: character-based chemistry, chemistry innovation, colligative properties, laboratory workbook, project-based learning

Citation: Nainggolan, B., Hutabarat, W., Situmorang, M., \& Sitorus, M. (2020). Developing Innovative Chemistry Laboratory Workbook Integrated with Project-based Learning and Characterbased Chemistry. International Journal of Instruction, 13(3), 895-908. https://doi.org/10.29333/iji.2020.13359a 


\section{INTRODUCTION}

The use of innovative chemistry laboratory workbook learning integrated with project packages that are packaged with computers is very appropriate to motivate students to learn independently in increasing their knowledge and skills in chemistry. With the rapid development of technological advances in the current era of industrial revolution 4.0 (IR 4.0) have supported teaching and learning education around the world (Mashadi \& Kargozan, 2011; Ragulina, Semenova, Zueva, Kletskova \& Belkina, 2018). The IR is defined as the development of knowledge in which the border lines between physical, digital and biological interests are being undetectable (Benešová \& Tupa, 2017). Industry 4.0 introduced in Germany in 2011 which is referred to the potential industrial revolution 4.0 in higher education and the teaching methods (Rojko, 2017).

It is known that the requirement for the future teachers are human-based on didactical, technological as well as organizational that introduced the teaching scenarios to cope with the current technological revolution Industry 4.0 (Abdelrazeq, Janssen, Tummel, Richert \& Jeschke, 2016). The first is direct student response systems that are required for collecting feedback and questions and display analysis through smart interface devices to record movements and detect student's physiological status and get direct feedback, so that, teachers know how far students have met learning objectives. The second scenario is known as teacher's self-feedback i.e. teachers uses wireless earphones and other notification devices to transfer self-feedback performance with wireless earphones and other notification devices during teaching and learning processes. It ensures that teachers and students will benefit from. The third scenario is multilingual Communication i.e. teaching multilingual students in the same classroom using wireless electronic translation devices, to translate information and allow students from different culture and languages to comprehend the presented subjects without any mistranslation. The teachers and students will see and hear the presented subject in their own language. As a result, it enables students to work under the same circumstances for achieving the learning objective successfully. The teacher will be able to answer the question without having to face communication barriers. This ultimately leads not only to greater activation, participation and understanding. In teaching and learning processes, implementation of learning have experience changes in paradigm from teacher-centred into student-centred based on the Industrial Development (ID) 4.0. As a result, information emerges in various kinds and relatively increases abundantly. The emerging of millennial generations which have digital competency and highly intelligence had made it difficult for teachers to cope with. As a result, in order to anticipate the introduction of industrial revolution (IR) 4.0, Indonesia has introduced the 2013 curriculum called Indonesian National Qualifications Framework which is intended to meet the industry 4.0 requirements (Mickelson, Kaplan \& Macneily, 2009; Habók \& Nagy, 2016).

Learning innovation is very appropriate to facilitate the learner to learn optimally, improve memory of learning, and make learning more effective and efficient. One of learning innovation that needs attention is project-based learning (Solomon, et al., 2018; Premo, Cavagnetto, Davis \& Brickman, 2018; Simaremare, Situmorang \& Tarigan, 2018; Hsiao, Tiao \& Chen, 2016). One of the teaching methods that suites the industry 
4.0 is problem-based learning method in which students working independently or collaboratively to solve problems given by the teachers. Chemistry is part of basic science subjects which is introduced at high school level and delivered through scientific approaches, and students find it difficult to cope with due to its complexity and abstract concepts. As a result, it should be delivered through experiences in laboratory (Emery \& Morgan, 2017). Teaching chemistry integrated with experiments would increase student motivation and skills and retain the knowledge longer in their memory. One of the chemistry competencies required by grade XII of the high school students is Colligative Properties of solutions that could be taught through computerized project-based learning in order to increase student motivation in studying the subject (Hutabarat, 2015). However, one of the problems faced by teachers is lack of innovative computerized chemistry laboratory workbook that meets student needs. It was found that, a number of Local or Conventional chemistry laboratory workbooks (ConChemLaW) available in local bookstores are not facilitated with computerized project-based learning. The purpose of this study is to develop an innovative Chemistry Laboratory Workbook (InoChemLaW) based on computerized and character-based chemistry that are integrated with projects that are suited to high school curriculum to be used as a learning resource to study chemistry.

\section{LITERATURE REVIEWS}

Project-based learning (PBL) is defined as collaborative learning in achieving final objectives (Grant, 2011; Hernández-Ramos \& De La Paz, 2009). The PBL is considered as situated learning which is based on constructivist theory. The main objective of constructive learning is to enhance student active participation and to support student motivation and self-directed learning in studying subject matters. To achieve the learning circumstances, teachers should provide students with multimedia to discover and design knowledge to meet learning environments (Sary, Situmorang \& Tarigan, 2018). It is due to the specific characteristic of the PBL methods that it could be used to promote important skills needed by students to accomplish learning objectives. However, it should be taken into account to take precaution in integrating the technology into the school curriculum, since it was reported that students often unable to connect them and teachers also often have great difficulty in designing classroom tasks to meet the students' needs (Lo \& Hew, 2017). Recently, it was recommended to provide teachers with comprehensive knowledge in using new technology and implementing it in real class effectively and it is known as Teacher 4.0 which is referred to as future teachers who are capable to use new technology and implement it effectively in real classes.

The use of computer technology in classroom helps students to study chemistry effectively and motivate them to solve problems (Anwariningsih \& Ernawati, 2013). However, it has not been widely introduced into educational system especially computerized and character-based chemistry laboratory workbook integrated with project-based learning. The usage of computerized and character-based workbook is basically based on cognitive theory of multimedia learning theory which is fundamentally assumed that chemistry courses are delivered better and faster in words and pictures simultaneously than words alone (Martalina, Situmorang, Sudrajat, 2018). 
This assumption is considered as the main reason in applying computers into laboratory workbooks integrated with PBL. Furthermore, Mayer acknowledged the role of memory storages in multimedia learning strategy i.i. sensory memory which receives and stores information temporarily, working memory that process information and incorporated into previous knowledge and long term memory that stores the information studied in many cases teachers do not need to use a sophisticated tool to deliver subjects, it depends on the subject and the suitability of the media such as for simple subject teachers can deliver orally. The chemistry courses generally consist of abstract concepts as results students find it difficult to master, and it generally memorized the concepts. (Rasul, Bukhsh, \& Batool, 2011; Othman, Treagust \& Chandrasegaran, 2008).

As a result of the development of Industrial Revolution (IR 4.0) the landscape of educational system has changed dramatically, where it is controlled by artificial intelligence that results student and internet interface faster than before. A faster revolution in education innovation is needed to meet the future of education 4.0 in order to prepare students for future life and work. As a result of vast development of IR 4.0 results in the future learning amazingly interesting. Science fiction moves toward real science, and creative energy has no limits, virtual and augmented reality crawls into smart classroom (Chan \& Zary, 2019; Popenici \& Kerr, 2017). As cutting edge teachers must be able to investigate new and creative strategy to upgrade and innovate future learning to meet the requirement of Education 4.0. Therefore, it is required to develop an innovative chemistry laboratory workbook (InoChemLaw): computerized and character-based chemistry laboratory workbook integrated with PBL using learning management system (EXE-Learning software) as a fundamental tool in developing the intended workbook, and suited to the Indonesian national curriculum. The Software is an open course which can be downloaded freely from internet.

It was also found that teachers have a positive attitude in using internet technology into education (Zyad, 2016). It is teacher responsibility to integrate technology into educational system and to promote inquiry, problem solving and critical thinking ability of the students (Khosrow-pour, 2014). When teachers from different disciplines designed and execute the lessons well, it is expected students to experience connections between the subject matters learned and obtain a meaningful comprehension of concepts and skills. It also assists student to use self-directed learning and promoting metacognitive reinforcement for retrieving and transferring knowledge (Piccinini \&. Scollo, 2006). In the PBL, the students investigate questions, propose hypotheses and explanations, discuss ideas, challenge ideas and try out new ideas, so that they usually get higher scores than students in conventional learning (Marx, et al., 2004; Rivet \& Krajcik, 2004). It was reported that learning science effectively occurs in an authentic and real world context. In situated learning generally students take a great role in scientific investigations, writing explanation, modelling, and discussing ideas with others. When students use the internet for scientific investigation and create a website to publish their project yields, it can increase student organizational skills and connect them with worldwide audiences (Zwick, 2018; ChanLin, 2008).

It is required to integrate technology into project-based learning by considering realworld scenarios and the students should take part in various activities. Therefore, during 
the learning activities, it needs to use scaffolding systematically in order to support the students, focus on the tasks, environment, the students and the society. In order to encourage students to work cooperatively and constructively they should take part in novice programs. A study of integrating knowledge of life science and information technology were reported, it was concerning with the nature of experience in the PBL tasks and the learning achievement based on student's roles in the tasks (Jin \& Bridges, 2014; Hung, Chee, Hedberg \& Seng, 2005). It was also known that computers have been used as a tool of communication for the PBL to teach about process of skills such as note taking, viewing and citing articles through internet and creating a product. The project-based learning has been widely used in Higher Education to promote quality and effectiveness of teaching and learning (Torres, Sriraman \& Ortiz, 2019). Introducing the PBL has successfully been done to high school students to design a personal heating using his/her own previous knowledge in chemistry and engineering subjects (Laur, 2013; Adams, et al., 2011; Apedoe, Reynolds, Ellefson \& Schunn, 2008).

It was reported that student attendance increased when subject delivered using PBL method due to their satisfaction in planning, designing and testing the products. To optimise the learning, the method has been integrated with computer technology resulting students to take part in scientific inquiry and increasing student interests in constructing new knowledge from technological skills and experiences (Kanaya, Light $\&$ Culp, 2005). In this case, integrating technology computer into educational system meet student's needs and interest rather than training the students to accomplish instructional objectives. The usage of web-page design tool enhanced students to organize and construct new knowledge based on the PBL. They devoted to learning form the PBL activities. It was found that PBL objectives were met. They usually responsible worked in groups and discovered scientific knowledge via collaborative activities through investigation and exploration. Furthermore, the success of the PBL lies in the students and teachers collaboration in constructing knowledge. It is greatly important for students to get involve in self-exploratory experiences in implementing technology computer into PBL. In addition, the teachers should guide them to do metacognitive processes in achieving the tasks. It is urgent that science classroom facilitated with technology needed so they have easy access to technology. It is due to the fact that they need more times to elaborate skills using internet and preparing for final papers. In addition, knowledge development and technological competencies can be accomplished through comprehensive experiences and opportunities. Students involvement and confidence in using technology is required in order to develop interpersonal skills and healthy collaboration among group members of the PBL In PBL students usually learn from group discussion through collaborative learning. Sometimes, they disagree on the subject discussed and conflict occurs among group members, which reflects healthy interaction among group members (Aguilar \& Pifarre Turmo, 2019).

It was reported that teacher helped students in learning to deal with conflict in group learning by advising them to use appropriate communication skills. How to develop students' personal, interactive and communication skills usually discuss in group-based learning approach (Livingstone \& Lynch 2002; Livingstone \& Lynch 2000). It is reported that integrating technology into learning will enhance students to construct on 
things that you learned from technological skills and experiences based on their previous knowledge and related to learning process (ChanLin, 2008).

\section{METHOD}

\section{Research procedures}

The research was conducted at the 14th Public High School, Medan-Indonesia. The development of an innovative chemistry laboratory workbook (InoChemLaW) on Colligative Properties of solutions was conducted followed the procedures explained in the references (Situmorang, et al., 2018; Dick, Carrey \& Carey, 2005). The research procedures consist of syllabus analysis, chemistry laboratory workbook analysis, design and development of the workbook, implementation, evaluation and data analysis as summarised in Figure 1.

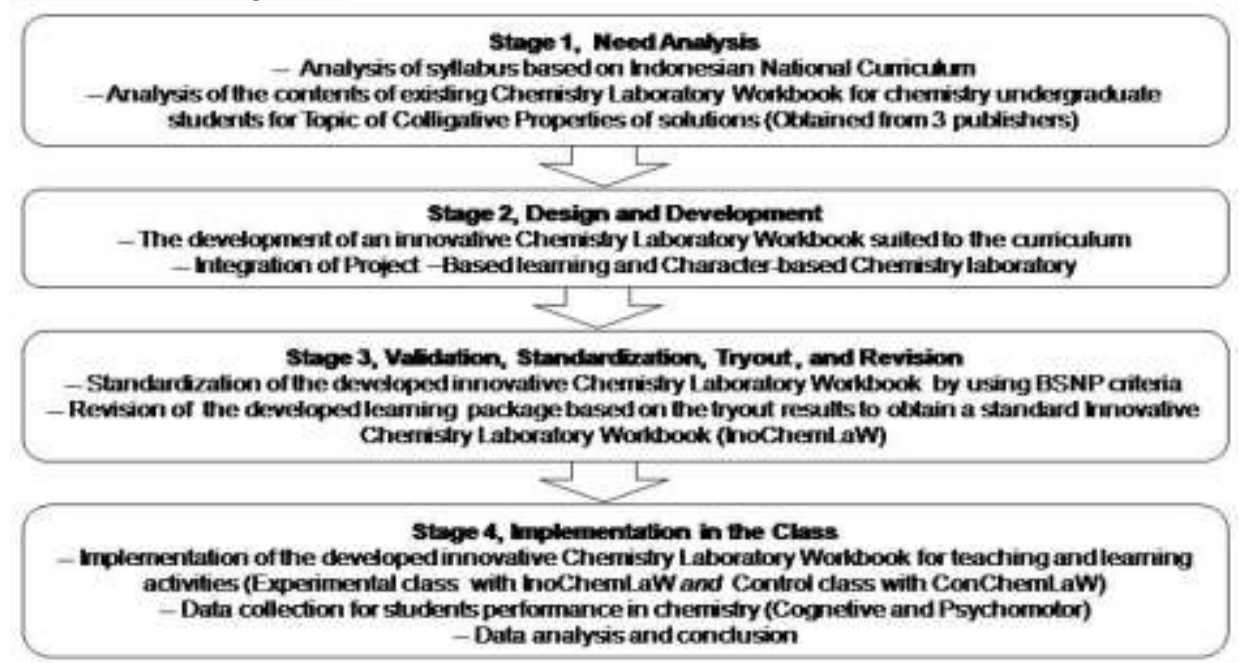

Figure 1

The Stages of the Development, Standardization, and Implementation of the InoChemLaW on the Teaching of Colligative Properties of Solutions

\section{The Development and Standardization of InoChemLaW}

The existing Chemistry laboratory Workbook (ConChemLaW) samples were selected from three local publishers and analyzed for its contents suited to the students' needs, followed by the development of the innovative laboratory workbook package. Before the investigation was carried out, the chemistry syllabus of grade 12 and the ConChemLaW workbooks was analyzed for its contents and its suitability for the need of high school students. The design of an InoChemLaW package was then developed with the integration of project-based learning and character-based chemistry laboratory. The developed laboratory workbook was then standardized by the expert of lectures from the Department of Chemistry, Universitas Negeri Medan and experienced chemistry teachers from the Public High School to find out the weaknesses and strengths of the workbooks. Questionnaires were distributed to the lecturer and teacher to validate 
the ConChemLaW Workbook based on the National Education Standards Board [Badan Standar Nasional Pendidikan] (BSNP) indicators, those are the feasibility in the content, language, display, and delivery (Situmorang, Sitorus, Hutabarat \& Situmorang, 2015).

\section{Implementation of InoChemLaW}

Two sample classes of grade 12 from the high school were selected purposively, where the first class of grade 12th of the 4th science class was treated as the experimental class (taught with the InoChemLaW package, and the second class of grade 12 of the 5th science class was treated as controlled group (taught with the ConChemLaW package). An InoChemLaW package was then implemented toward the experimental group and compared with the controlled group which was treated with ConChemLaW. Both groups class were given pre-test before the teaching treatment has been carried out, followed by the teaching and learning activities by using the InoChemLaW and ConChemLaW workbooks to experiments class and control class respectively. The InoChemLaW workbook was presented through the learning management system EXE-Learning. At the end of the class, they were given a post-test concerning the subject being taught. During the classroom activities, the teachers observed student activities for affective performance by using the checklist evaluation sheet. Students' performances in the form of learning achievement (cognitive) were recorded by using evaluation tests, while the character-chemistry skills (psychomotor) measurement were carried out by using checklist rubrics. Hypothesis testing was tested after normality and homogeneity test were carried out.

\section{FINDINGS}

\section{Need Analysis for Chemistry Laboratory Workbook}

The existing chemistry laboratory workbook for the subject of Colligative Properties of Solutions has been analyzed to see the suitability of the contents of the book with the needs of high school students by using indicators set by the BSNP criteria and the national curriculum. The results of the analysis of the contents of chemical material, language and presentation are summarized in Table 1.

Table 1

Assessments Results from Expert Respondents on the Feasibility of the ConChemLaW Package that are Selected from Various Publishers

\begin{tabular}{lllll}
\hline \multirow{2}{*}{ Publisher Code } & \multicolumn{5}{l}{ Feasibility scores $(n=6)^{*}$} & \\
\cline { 2 - 5 } & Content & Language & Presentation & Display \\
\hline A & 2.68 & 3.26 & 3.28 & 2.84 \\
B & 2.56 & 3.16 & 3.24 & 3.08 \\
C & 2.82 & 3.12 & 3.18 & 2.96 \\
\hline Average & 2.69 & 3.18 & 3.23 & 2.96 \\
\hline * &
\end{tabular}

*Marking criteria: 4 = very good; 3 = good; 2 = poor, and $1=$ very poor

The weakness of these ConChemLaW package have been noted. They were all not provided with chemical equipment and application of the Colligative Properties of Solutions, such as the sub-topic of: effect of boiling point increased, decreasing freezing point, and osmotic pressure in daily life. It was also not provided with laboratory basic 
techniques and skills, and the illustrations are not well designed and colored, but the content of the workbooks were relatively good. In addition, the workbooks were not facilitated with project-based learning and characters-based chemistry integrated with technological computers. Furthermore, an innovation was made to the chemistry laboratory workbook by fixing all the weaknesses contained in ConChemLaW package, and then completing the book section with project-based learning and characters-based chemistry integrated with computer technology in accordance with student characteristics to produce an InoChemLaW package. The developed InoChemLaW are equipped with: (1) General implementation guides i.e. practicum guidelines, laboratory safety, equipment safety, waste handing, and toxicity indicators (corrosive, oxidizer, explosive and flammable substances); (2) Complete material of the topic for Colligative Properties of Solutions implication in daily life such as, effect of boiling point elevation and freeing point depression and osmotic pressure effects on blood; (3) Illustrations, figures and the list of chemical equipments; (4) Basic laboratory technical and basic skills provided i.e. how to mix, shake, heat, filter, and smell solutions; (5) Experimental procedures, project-based learning and characters-based chemistry are integrated with technological computers.

\section{Standardization of Innovative Chemistry Laboratory Workbook}

Teaching material of an innovative chemistry laboratory workbook has been standardized using experts, namely chemistry lecturers and experienced chemistry teachers, and respondents' responses to the feasibility of an InoChemLaW are summarized in Table 2.

Table 2

Results of Expert Judgments (Lecturers and Teachers) to the Feasibility of a Developed InoChemLaW based on the BSNP Indicators

\begin{tabular}{lllll}
\hline \multirow{2}{*}{ Indicators } & \multicolumn{2}{l}{ Feasibility scores $(n=6)^{*}$} & Average & \multirow{2}{*}{$\begin{array}{l}\text { Standard } \\
\text { Criteria }\end{array}$} \\
\cline { 2 - 3 } & Lecturers & Teachers & & Highly valid \\
\hline Content & 3.38 & 3.24 & 3.31 & Highly valid \\
Language & 3.46 & 3.28 & 3.37 & valid \\
Presentation & 3.28 & 3.16 & 3.22 & Valid \\
Display & 3.18 & 3.12 & 3.15 & \\
\hline
\end{tabular}

*Marking criteria: 4 = very good; 3 = good; 2 = poor, and 1 = very poor

From these results it is known that an InoChemLaW package have met the requirements to be used as a support chemistry material in learning activities in teaching of Colligative Properties of Solutions. All chemistry teacher and teacher respondents gave positive responses to the feasibility of innovative teaching materials so that the developed innovative learning package could be implemented in learning chemistry.

\section{Implementation of Innovative Chemistry Laboratory Workbook}

Teaching chemistry for the subject of Colligative Properties of Solutions is carried out according to a predetermined schedule of the experimental group and the control group. The chemistry topic in an InoChemLaW teaching material has been implemented in the experimental class, and as a comparison a ConChemLaW is used in the control class. Students' performances recorded as learning achievement (cognitive) from evaluation 
tests and the character-chemistry skills (psychomotor) obtained from observation checklist, for both groups are summarized in Table 3.

Table 3

Students' Performances based on Learning Achievement and the Character-Chemistry Skills

\begin{tabular}{|c|c|c|c|c|}
\hline \multirow[t]{2}{*}{ No } & \multirow{2}{*}{$\begin{array}{l}\text { Students } \\
\text { performances }\end{array}$} & \multicolumn{2}{|l|}{ Students Score $(M \pm S t d v)$} & \multirow{2}{*}{$\begin{array}{l}\text { Hypothesis testing (t- } \\
\text { test) }\end{array}$} \\
\hline & & Experimental Class $(n=30)$ & Control Class $(n=30)$ & \\
\hline 1 & Pre-test & $32.0 \pm 7.9$ & $36.3 \pm 8.6$ & $\mathrm{t}_{\mathrm{cal}} 0.0691<\mathrm{t}_{\text {table }} 1.678$ \\
\hline 2 & Post-test & $86.0 \pm 3.1$ & $79.8 \pm 2.5$ & $\mathrm{t}_{\mathrm{cal}} 4.641>\mathrm{t}_{\text {table }} 1.678$ \\
\hline 3 & Psychomotor & $86.8 \pm 5.6$ & $78.5 \pm 5.5$ & $\mathrm{t}_{\mathrm{cal}} 3.156>\mathrm{t}_{\text {table }} 1.678$ \\
\hline
\end{tabular}

The results from pre-test showed that the average academic ability of students before learning is relatively low for both experimental group $(M=32.0 \pm 7.9)$ and control group $(\mathrm{M}=36.3 \pm 8.6)$, and the two groups are $\left(\mathrm{t}_{\text {cal }} 0.0691<\mathrm{t}_{\text {table }} 1.678\right)$. In this case both groups of students do not understand the chemistry subject matter that are being evaluated. The effect of using an InoChemLaW in the classroom is very real showing differences in students' academic abilities. The results of the evaluation of learning after learning activities have carried out showed that student learning achievement in the experimental group $(\mathrm{M}=86.0 \pm 3.1)$ is higher than the achievement of students in the control group $(\mathrm{M}=79.8 \pm 2.5$ ) who only used ConChemLaW, and the two groups were significantly different $\left(\mathrm{t}_{\text {cal }} 4.641>\mathrm{t}_{\text {table }} 1.678\right)$.

Study chemistry by using the developed InoChemLaW aims to improve student learning independence by doing the chemistry projects guided by an innovative learning package, so that students have the ability to conduct chemical experiments correctly. The student performance based on character-chemistry skills (psychomotor) assessment rubric has been observed as summarized in Table 3 . The results showed that students' psychomotor skills in the experimental group $(\mathrm{M}=86.8 \pm 5.6)$ were found higher when compared to the skills obtained by the control group $(\mathrm{M}=78.5 \pm 5.5)$, and two groups were significantly different $\left(\mathrm{t}_{\mathrm{cal}} 3.156>\mathrm{t}_{\text {table }} 1.678\right)$. It can be stated that learning chemistry by using InoChemLaW can improve students' knowledge and psychomotor simultaneously.

\section{DISCUSSION}

A needs analysis to the existing chemistry laboratory workbook has been carried out as a basis to build an innovative chemistry laboratory workbook so that it meets the needs and feasibility as a learning package to be used to learn the chemistry topic of Colligative Properties of solutions. All weaknesses found in ConChemLaW are corrected through innovation by adding projects and proper character-based chemistry suited to high school students. Emphasis on laboratory safety is also carried out as a precaution in handling the chemicals and reagents. An innovative workbook package has been integrated with computer technology. The developed InoChemLaW package can motivate students to study chemistry, improve scientific inquiry, and also encourage the formation of new knowledge through investigations (Abdelrazeq, Janßen, Tummel, Richert \& Jeschke, 2016). Therefore, integrating technology computers into the educational system will meet student's needs and interests rather than training the students to accomplish instructional objectives (Kanaya, et al., 2005). 
The implementation of an InoChemLaW in learning helps students to learn systematically followed the character-based chemistry. In line with technological advances, students tend to use InoChemLaW packaged that is equipped with illustrations, figures and the hyperlink for future study. Examples of project packages that are available in the InoChemLaW are very interesting to students, so they can do laboratory activities correctly, and safety is greatly maintained by students when doing laboratory activities (Slade, Raker, Kobilka \& Pohl, 2014; Gooding, Yang \& Situmorang, 2001). An InoChemLaW learning package carried out in this study has been able to improve student learning outcomes. Groups of students who were given learning using InoChemLaW shown to have higher learning performances. It was also found that the cognitive and psychomotor scores of the experimental groups respectively were higher than the controlled group. Observations on teaching and learning activities of students who were given the InoChemLaW package proved to be more active than the groups that were given ConChemLaW. It was because the innovative workbook integrated with computers that met IR 4.0. Integrated project-based learning can build students' knowledge through independent study (Tan \& Chapman, 2016). The learning activities through conducting the project work will develop student's creativity in problem-solving (Simaremare, Situmorang \& Tarigan, 2018; Martalina, Situmorang \& Sudrajat, 2018). These results are consistent with findings made using innovative learning in chemistry teaching in tertiary institutions (Sinaga, Situmorang, \& Hutabarat, 2019; Purba, Situmorang \& Silaban, 2019). The skills in the field of chemistry have been obtained through teaching and learning activities in the classroom, laboratory, and field study (Pedersen \& Myers, 2011; Solomons, Fryhle \& Snyder, 2014). It enhanced students' ability to construct things from what they learned from technological skills and experiences based on their previous knowledge and it increases student achievements (Santyasa, Rapi \& Sara, 2020; Kızkapan \& Bektaş, 2017; ChanLin, 2008). Projectbased learning improved students ability to work within teams (Shernoff, Sinha, Bressler \& Schultz, 2017).

\section{CONCLUSION}

Innovative chemistry laboratory workbook for the topic of Colligative Properties of Solutions has been developed through the needs analysis stage following the demands of the national curriculum. The InoChemLaW package is equipped with projects and character-based chemistry that can build student ability in the investigation, and integrated with computer technology to make it simple to attract students to study independently. Experts' standardization showed that the InoChemLaW package has fulfilled the BSNP requirements for secondary schools. Implementation of the InoChemLaW increased student performance where students' performance in cognitive and psychomotor skills in the experimental group were found higher than the controlled group. It was since the innovative workbook integrated with computers and based on the BSNP indicators met IR 4.0. Therefore, teachers and students interacted with others using internets during teaching and learning processes. In other words, universities and higher education have to find solutions to the new and innovative computer technology developments. 


\section{RECOMMENDATIONS}

It needs to facilitate schools with computers and webs to have access to find new information and data in supporting the InoChemLaW workbooks. So that teachers can cope with the new requirement of the teaching performances. Therefore, universities must be responsible to give support to teachers in coping with the new technology developments.

\section{AKNOWLEDGEMENT \\ I would like to thank the Directorate of Research and Community Service of the Ministry of Research and Technology and Higher Education, for financial assistance with a research grant number 12/UN33.8/PL.DPRM/2019. The English proofreading process from Isli Iriani Pane from the Language Centre of Universitas Negeri Medan is also acknowledged.}

\section{REFERENCES}

Abdelrazeq, A., Janssen, D., Tummel, C., Richert, A., \& Jeschke, S. (2016). Teacher 4.0: requirements of the teacher of the future in context of the fourth industrial revolution. Paper presented 9th International Conference of Education, Research and Innovation. 14-16 November 2016, Seville, Spain.

Adams, S., DeCastro, P., Echenique, P., Estrada, J., Hanwell, M. D., Murray-Rust, P., Sherwood, P., Thomas, T., \& Townsend, T. (2011). The Quixote project: Collaborative and open quantum chemistry data management in the internet age. Journal of Cheminformatics, 3, 38, doi:10.1186/1758-2946-3-38.

Aguilar, D., \& Pifarre Turmo, M. (2019). Promoting social creativity in science education with digital technology to overcome inequalities: A scoping review. Frontiers in psychology, 10, 1474. doi:10.3389/fpsyg.2019.01474.

Anwariningsih, S. H., \& Ernawati, S. (2013). Development of interactive media for ICT learning at elementary school based on student self learning. Journal of Education and Learning, 7(2), 121-128.

Apedoe, X. S., Reynolds, B., Ellefson, M. R., \& Schunn, C. D. (2008). Bringing engineering design into high school science classrooms: The heating/cooling unit. $J$. of Science Education \& Technology, 17, 454-465, doi:10.1007/s10956-008-9114-6.

Benešová, A., \& Tupa, J. (2017). requirements for education and qualification of people in industry 4.0., Procedia Manufacturing, 11, 2195-2202.

Chan, K. S., \& Zary, N. (2019). Applications and challenges of implementing artificial intelligence in medical education: Integrative review. JMIR Medical Education, 5(1), e13930. doi:10.2196/13930.

ChanLin, L. J. (2008) Technology integration applied to project-based learning in science, Innov. in Edu. and Teac. Int., 45(1), 55-65, doi: 10.1080/14703290701757450 Dick, W., Carrey, L., \& Carey, O. J. (2005). Systematic design of instruction. Allyn \& Bacon.

Emery, L. R., \& Morgan, S. L. (2017). The application of project-based learning in bioinformatics training. PLoS Comput Biol, 13(8), e1005620. 
Gooding, J. J., Yang, W. R., \& Situmorang, M. (2001), Bioanalytical experiments for the undergraduate laboratory: Monitoring glucose in sport drinks. Journal of Chemical Education, 78(20), 788-790. Doi:10.1021/ed078p788.

Grant, M. (2011). Learning, beliefs, and products: Students' perspectives with projectbased learning. The Interdisciplinary Journal of Problem-Based Learning, 5(2), 37-69.

Habók, A., \& Nagy, J. (2016). In-service teachers' perceptions of project-based learning. SpringerPlus, 5, 83. doi:10.1186/s40064-016-1725-4.

Hernández-Ramos, P., \& De La Paz, S. (2009). Learning history in middle school by designing multimedia in a project-based learning experience. Journal of Research on Technology in Education, 42(2), 151-173. doi: 10.1080/15391523.2009.10782545.

Hsiao, C. C., Tiao, M. M., \& Chen, C. C. (2016). Using interactive multimedia e-Books for learning blood cell morphology in pediatric hematology. BMC Medical Education, 16(1), 290. doi:10.1186/s12909-016-0816-9.

Hung, D., Chee, T. S., Hedberg, J. G., \& Seng, K. T. (2005). A framework for fostering a community of practice: Scaffolding learners through an evolving continuum. British Journal of Education Technology, 36(2), 159-76.

Hutabarat, W. (2015). Investigation of teacher job-performance model: Organizational culture, work motivation and job-satisfaction, Asian Social Science, 11(18), 295-304.

Jin, J., \& Bridges, S. M. (2014). Educational technologies in problem-based learning in health sciences education: A systematic review. Journal of Medical Internet Research, 16(12), e251. doi:10.2196/jmir.3240.

Kanaya, T., Light, D., \& Culp, K. M., (2005). Factors influencing outcomes from a technology-focused professional development program. Journal of Research on Technology in Education, 37(3), 313-329. doi: 10.1080/15391523.2005.10782439.

Khosrow-pour, M. (2014). Educational technology use and design for improved learning opportunities, Publish in The United States of America by Information Science References.

Kızkapan, O., \& Bektaş, O. (2017). The effect of project based learning on seventh grade students' academic achievement. International Journal of Instruction, 10(1), 3754. doi: 10.12973/iji.2017.1013a.

Laur, D. (2013). Authentic learning experiences, a real-world approach to projectbased learning. Eye on education. New York: Routledge.

Livingstone, D., \& Lynch, K. (2000). Group project work and student-centred active learning: Two different experiences. Studies in Higher Education, 25(3), 325-345. doi: $10.1080 / 713696161$.

Livingstone, D., \& Lynch, K. (2002). Group project work and student-centred active learning: Two different experiences. Journal of Geography in Higher Education, 26(2), 217-237, doi: 10.1080/03098260220144748.

Lo, C. K., \& Hew, K. F. (2017). A critical review of flipped classroom challenges in K12 education: possible solutions and recommendations for future research. Res and Practice in Technology Enhanced Learning, 12(1), 4. doi:10.1186/s41039-016-0044-2. 
Martalina, D. S., Situmorang, M., \& Sudrajat, A. (2018). The development of innovative learning material with integration of project and multimedia for the teaching of gravimetry. Advances in Social Science. Education and Humanities Research, 200, 735-740. Doi: 10.2991/aisteel-18.2018.160.

Marx, R. W., Blumenfeld, P. C., Krajcik, J. S., Fishman, B., Soloway, E., Geier, R., \& Revital, T. T. (2004). Inquiry-based science in the middle grades: Assessment of learning in urban systemic reform. J of Res in Science Teaching, 41(10), 1063-1080.

Mashadi, V. Z., \& Kargozan, M. R. (2011). Influences of digital classrooms on education. Procedia Computer Science, 3(11), 1178-1183.

Mickelson, J. J., Kaplan, W. E., \& Macneily, A. E. (2009). Active learning: A resident's reflection on the impact of a student-centred curriculum. Canadian Urological Association J = Journal de l'Association des urologues du Canada, 3(5), 399-402.

Othman, J., Treagust, D. F., \& Chandrasegaran, A. L. (2008). An investigation into the relationship between student's conception of the particulate nature of matter and their understanding of chemical bonding. Int J of Science Education, 30(11), 1531-1550.

Pedersen, S. F., \& Myers, A. F., (2011). Understanding the principle of organic chemistry, a laboratory course. Belmont: Brooks/Cole, Cengage Learning.

Piccinini, N., \& Scollo, G. (2006). Cooperative project-based learning in a web-based software engineering course. Journal of Educational Technology \& Society, 9(4), 54-62.

Popenici, S., \& Kerr, S. (2017). Exploring the impact of artificial intelligence on teaching and learning in higher education. Research and Practice in Technology Enhanced Learning, 12(1), 22. doi:10.1186/s41039-017-0062-8.

Premo, J., Cavagnetto, A., Davis, W. B., \& Brickman, P. (2018). Promoting collaborative classrooms: The impacts of interdependent cooperative learning on undergraduate interactions and achievement. CBE Life Sciences Education, 17(2), ar32. doi:10.1187/cbe.17-08-0176.

Purba, J., Situmorang, M., \& Silaban, R. (2019). The development and implementation of innovative learning resource with guided projects for the teaching of carboxylic acid topic. Indian J of Pharm Edu and Res, 53(4), 603-612. doi: 10.5530/ijper.53.4.121.

Ragulina, Y. V., Semenova, E. I., Zueva, I. A., Kletskova, E.V., \& Belkina, E. N., (2018). Perspectives of solving the problems of regional development with the help of new internet technologies. The Int J Entrepreneurship and Sustainability, 5(4), 890-898.

Rasul, S., Bukhsh, Q., \& Batool, S. (2011). A study to analyze the effectiveness of audio visual aids in teaching learning process at university level. Procedia - Social and Behavioral Sciences, 28, 78-81.

Rivet, A., \& Krajcik, J. (2004). Achieving standards in urban systemic reform: An example of a sixth grade project-based science curriculum. Journal of Research in Science Teaching, 41(7), 669-692

Rojko, A. (2017). Industry 4.0 concept: Background and overview. International Journal of Interactive Mobile Technologies, 11(5), 77-90.

Santyasa, I. W., Rapi, N. K., \& Sara, I. W. W., (2020), Project based learning and 
academic procrastination of students in learning physics. Int $J$ of Ins, 13(1), Online F. Sary, S. P., Situmorang, M., \& Tarigan, S. (2018). Development of innovative learning material with multimedia to increase student achievement and motivation in teaching acid base titration. Advances in Social Science. Education and Humanities Research, 200, 422-425. Doi:10.2991/aisteel-18.2018.91.

Shernoff, D. J., Sinha, S., Bressler, D. M., \& Schultz, D. (2017). Teacher perceptions of their curricular and pedagogical shifts: Outcomes of a project-based model of teacher professional development in the next generation science standards. Frontiers in Psychology, 8, 989. doi:10.3389/fpsyg.2017.00989.

Simaremare, S., Situmorang, M., \& Tarigan, S., (2018). Innovative learning material with project to improve students achievement on the teaching of acid-base equilibrium. Adv in Soc Sci. Edu and Hum Res, 200, 431-436. doi.org/10.2991/aisteel-18.2018.93.

Sinaga, M., Situmorang, M., \& Hutabarat, W. (2019). Implementation of innovative learning material to improve students competence on chemistry. Indian $J$ of Pharmaceutical Education and Research, 53(1), 28-41. doi:10.5530/ijper.53.1.5.

Situmorang, M., Sinaga, M., Purba, J., Daulay, S. I., Simorangkir, M., Sitorus, M., \& Sudrajat, A. (2018). Implementation of innovative chemistry learning material with guided tasks to improve students' competence. J of Baltic Sci Edu, 17(4), 535-550.

Situmorang, M., Sitorus, M., Hutabarat, W., \& Situmorang, Z. (2015). The development of innovative chemistry learning material for bilingual senior high school students in Indonesia. International Educational Studies, 8(10), 72-85. doi:10.5539/ies.v8n10p72.

Slade, M. C., Raker, J. R., Kobilka, B., \& Pohl, N. L. (2014). A research module for the organic chemistry laboratory: Multistep synthesis of a fluorosis dye molecule. Journal of Chemical Education, 91(1), 126-130. doi:10.1021/ed300375v.

Solomon, E. D., Repice, M. D., Mutambuki, J. M., Leonard, D. A., Cohen, C. A., Luo, J., \& Frey, R. F. (2018). A mixed-methods investigation of clicker implementation styles in STEM. CBE Life Sciences Education, 17(2), ar30. doi:10.1187/cbe.17-08-0180

Solomons, T. W. G., Fryhle, C. B., \& Snyder, S. A., (2014). Organic chemistry. John Wiley \& Sons.

Tan, J. C. L., \& Chapman, A. (2016). Project-based learning for academically-able student. Rotterdam: Sense Publishers.

Torres, A. S., Sriraman, V., \& Ortiz, A. M. (2019). Implementing project based learning pedagogy in concrete industry project management. Int Journal of Construction Education and Research, 15(1), 62-79. doi: 10.1080/15578771.2017.1393475.

Zwick, M. (2018). The design, implementation, and assessment of an undergraduate neurobiology course using a project-based approach. Journal of Undergraduate Neuroscience Education, 16(2), 131-142.

Zyad, H. (2016). Integration computers in the classroom: Barriers and teachers' attitudes. International Journal of Instruction, 9(1), 65-78. 